IZA DP No. 4399

Does Military Draft Discourage Enrollment in Higher Education?

Evidence from OECD Countries

Katarina Keller

Panu Poutvaara

Andreas Wagener

September 2009 


\title{
Does Military Draft Discourage Enrollment in Higher Education? Evidence from OECD Countries
}

\author{
Katarina Keller \\ Susquehanna University
}

Panu Poutvaara

University of Helsinki

and IZA

\section{Andreas Wagener \\ University of Hannover}

\section{Discussion Paper No. 4399 \\ September 2009}

\author{
IZA \\ P.O. Box 7240 \\ 53072 Bonn \\ Germany \\ Phone: +49-228-3894-0 \\ Fax: +49-228-3894-180 \\ E-mail: iza@iza.org
}

\begin{abstract}
Any opinions expressed here are those of the author(s) and not those of IZA. Research published in this series may include views on policy, but the institute itself takes no institutional policy positions.

The Institute for the Study of Labor (IZA) in Bonn is a local and virtual international research center and a place of communication between science, politics and business. IZA is an independent nonprofit organization supported by Deutsche Post Foundation. The center is associated with the University of Bonn and offers a stimulating research environment through its international network, workshops and conferences, data service, project support, research visits and doctoral program. IZA engages in (i) original and internationally competitive research in all fields of labor economics, (ii) development of policy concepts, and (iii) dissemination of research results and concepts to the interested public.
\end{abstract}

IZA Discussion Papers often represent preliminary work and are circulated to encourage discussion. Citation of such a paper should account for its provisional character. A revised version may be available directly from the author. 
IZA Discussion Paper No. 4399

September 2009

\section{ABSTRACT}

\section{Does Military Draft Discourage Enrollment in Higher Education? Evidence from OECD Countries}

Using data from 1960-2000 for OECD countries, we analyze the impact of compulsory military service on the demand for higher education, measured by students enrolled in tertiary education as a share of the working-age population. Based on a theoretical model, we hypothesize that military draft has a negative effect on education. Empirically, we confirm this for the existence of conscription, albeit usually at low statistical significance. However, the intensity of its enforcement, measured by the share of the labor force conscripted by the military and the duration of service, significantly reduces enrollment in higher education.

JEL Classification: H56, I20

Keywords: conscription, human capital

Corresponding author:

Panu Poutvaara

Department of Economics

University of Helsinki

Arkadiankatu 7 (P.O. Box 17)

00014 Helsinki

Finland

E-mail: panu.poutvaara@helsinki.fi 


\section{Introduction}

Compulsory military service and other types of mandatory civil or social service force young men - and sometimes women - to serve in the army or selected institutions in the civilian sector for a certain amount of time. Draft spells are typically issued when individuals are between 18 and 25 years, i.e., in a period of life that young adults typically spend studying, in vocational training, or gathering first experiences on the job. Being called to service interrupts or postpones this process of human capital accumulation, and given that they mark an important discontinuity in individual life cycles, military or alternative service may also go along with substantial anticipatory effects on young adults for their demand for education.

In this paper, we analyze the impact of military conscription on the demand for higher education in OECD countries over the period from 1965 to $20001^{1}$ Military recruitment practices vary considerably within this group of countries and over time: a few countries (e.g., the UK, Canada, New Zealand, and Japan) have had professional armies throughout the full period while several others have constantly relied on military conscription (e.g., Germany, Austria, and Turkey). Other countries (e.g., the US, Belgium and the Netherlands) changed their recruitment scheme between 1965 and 2000, switching from a draft system to a professional army. In particular, the years after the end of the Cold War saw a wave of European OECD countries (including France, Spain, and Italy) abolishing military conscription; some more countries are currently debating such a change. Yet, still 15 current OECD countries are using conscription, with the duration of the draft ranging from 4 to 18.5 months. ${ }^{2}$

Military service diminishes the individual returns to human capital. If military service interrupts studies, it will take a longer time to complete higher education. In addition, previously acquired skills and knowledge may depreciate during military service, and their recovery would require extra education. Finally, military service shortens the active period on the job one has chosen. All these effects can be expected to reduce the amount of education (in particular, of post-secondary schooling) that a student desires to obtain. In some instances, there may be a partially offsetting effect if university enrollment provides an opportunity to postpone and possibly avoid being drafted (see below). Yet, prima facie empirical

\footnotetext{
${ }^{1}$ For the sake of comparability we focus on countries that joined the OECD before 1994. This excludes former Socialist countries, Mexico and South Korea. We also exclude Iceland, which has no military, and Luxembourg, which had no university during this time. The remaining OECD countries in our sample are: Australia, Austria, Belgium, Canada, Denmark, Finland, France, Germany, Greece, Ireland, Italy, Japan, the Netherlands, New Zealand, Norway, Portugal, Spain, Sweden, Switzerland, Turkey, the United Kingdom and the United States (US). Data for Germany is only included since reunification.

${ }^{2}$ With the exception of Turkey, all OECD countries in our sample with military conscription offer conscientious objectors to bearing arms the option of an alternative service, typically to be delivered in the social sector.
} 
evidence suggests that the use of conscription is associated with lower enrollment rates in higher education. For 22 OECD-countries, Table 1 reports separately for countries with and without military draft, the average shares of people at college age that were actually participating in tertiary education. While the enrollment rate increased considerably everywhere, countries with conscription exhibit consistently lower rates of higher education enrollment (the difference amounted to more than 15 percentage points in the mid-1990s). These education gaps are the object of our study.

\section{INSERT TABLE 1 HERE.}

There are a small number of empirical studies that look at the impact of military service (during and outside of wartimes) on educational attainments and earnings over the life cycle of ex-soldiers. These studies, which are reviewed in more detail below and which deliver somewhat mixed evidence, focus on single countries and micro-data. Cipollone and Rosolia (2007) have recently shown that the adverse educational effects of male conscription may also extend to females due to social interaction. This suggests that the effects of conscription should be studied not only at the individual level but more widely. Therefore, our focus is on the economy-wide demand for higher education, and how this is affected by the prevalence and volume of military conscription in a country.

From an economy-wide perspective, the impact of conscription is less clear-cut than at the individual level. The alternative of military draft, the all-volunteer force, typically comes at higher budgetary costs and, thus, ceteris paribus, requires a higher level of general taxation. At least to the extent that taxes are levied on labor income, they reduce the returns to human capital and potentially have a negative effect on the incentives to invest in education. Fully analyzing the question whether military draft unfavorably affects human capital accumulation therefore requires a general-equilibrium model that can deliver a meaningful comparison between armies with draftees and all-volunteer forces. In this paper, we propose such a model. Our main theoretical prediction is that, relative to a tax-financed all-volunteer force of equal military output, conscription involves a lower equilibrium level of investment in education.

Using OECD panel data in five-year periods from 1960-2000, we test this prediction empirically. We research the impact of military conscription on higher education, measured by students enrolled in higher education as a share of the working-age population. We find that the existence of conscription indeed has a negative effect on enrollment in higher education, albeit of little statistical significance after control variables are added. However, the intensity of its enforcement, measured by conscripts as a share of the labor force and the time of military service, significantly reduces enrollment in higher education. Military expenditures and the share of the labor force employed by the military whether using conscripted or professional recruits have positive effects on college enrollment, but the latter is usually statistically insignificant. Moreover, a high income 
per working-age person, a high unemployment rate, and expanding secondary enrollment augment enrollment in higher education.

The rest of the paper is organized as follows: Section 2 reviews the literature on military conscription and its impact on human capital. In Section 3, a simple theoretical model is set up that serves as a basis for our empirical study, outlined in Section 4. The regression results are discussed in Section 5. Section 6 concludes.

\section{Military Conscription and Human Capital}

Since Adam Smith, most economists have argued that despite its lower budgetary cost for the government, a draft system is socially more costly than an all-volunteer force. Most arguments in that discussion focus on static inefficiencies of the draft system (Hansen and Weisbrod, 1967; Fisher, 1969; Lee and McKenzie, 1992; Sandler and Hartley, 1995, Chapter 6; Warner and Asch, 2001), such as output losses due to an inefficient matching of people's skills and tasks, foregone benefits from specialization, and factor misallocations in the military due to distorted price signals. In addition, Lau et al. (2004) argue that conscription creates dynamic and long-term costs absent from a professional military. The military draft afflicts young adults during the period of life when most human capital accumulation occurs, e.g. in education, vocational training, and early work experience that conscription interrupts or postpones. In addition, human capital accumulated before the draft depreciates during service, e.g. technical skills. Thus, the economy's stock of human capital is reduced (Spencer and Woroniak, 1969). Moreover, the draft acts as an in-kind tax and is levied on young people. Compared to monetary taxation (e.g., to finance a professional military) the burden of the draft tax, measured in terms of the present value of the reduction of taxpayers' lifetime incomes, is higher. The front-loaded reduction in lifetime income discourages saving and capital accumulation, reducing also the physical capital stock in an economy with a military draft compared to an otherwise identical economy with a professional army.

With a lower stock of human and physical capital, the level and growth rate of national income tend to be lower than with an all-volunteer force. Simulations for a computational general equilibrium economy by Lau et al. (2004) demonstrate that these long-run costs of the draft are sizeable: If the whole population was subject to a draft (i.e., of one year at the age of 18), long-run GDP would be reduced by up to one percent, relative to an identical economy that has the same level of military output produced in an equally efficient professional army. Keller et al. (forthcoming) corroborate this view empirically; they show that for OECD countries both the level of income per working-age person and economic growth rates are reduced with conscription, especially the more intensively the labor force are involved in conscription and the longer time periods served in military 
or in alternative service.

A number of studies are devoted to the impact of military service on human capital or education. A first wave of studies proxied the human capital effects of military service by differences in lifetime earnings or wages. E.g., Imbens and van der Klaauw (1995) observe losses of up to 5 percent of lifetime earnings for Dutch draftees in the 1980s and early 1990s compared to non-conscripts. Assuming that income differences reflect differences in individual productivities, this indicates a substantial impact of military draft (which lasted 14 months for those sampled in the study) on marketable human capital. During times of war the effects are even larger. In the early 1980s, the earnings of white Vietnam War veterans were 15 percent lower than the earnings of comparable non-veterans (cf. Angrist, 1990). Contradicting conventional wisdom, Angrist and Krueger (1994) show that veterans of World War II earn less than their non-veteran counterparts; the spurious positive impact of military service on earnings that emerges from cross-sectional data is traced back to the non-random draft selection mechanism utilized by the US military. For Germany, compulsory service leads to increases in wage income for men by 3.2 percent during the first year after conscription and depresses wage income beyond the first year, where the wage gap increases over time (Kunze, 2002).

More recent studies analyze whether there is a direct link between conscription and educational enrollment or achievements. Maurin and Xenogiani (2007) find that higher education enrollment of males in France has decreased since conscription was (de facto) abolished in 1997 for men born in 1979 or later. For women, enrollment has not changed in that period. Maurin and Xenogiani (2007) point to the fact that some men may have attended higher education to postpone their military duties, possibly hoping to completely circumvent service even at a later date. A similar effect is shown by Card and Lemieux (2001) for males at risk of being drafted into the US Army during the Vietnam War. College deferment being an effective means of draft avoidance raised college attendance of draft-age males by four to six percentage points. Card and Lemieux (2001) argue that this increase is significant but not economically substantial. Bound and Turner (2002) analyze post-secondary educational attainment of American World War II veterans. The US government set up widely available and generous college funding for ex-soldiers (the G.I. Bill), but educational attainments of veterans nevertheless rose only very moderately, compared to non-veteran peers. Bound and Turner (2002) are not able to econometrically separate the effects of military service and education subsidization but argue that the effect of war participation alone is probably small. Buonanno (2006) analyzes the effects of the abolition of compulsory military service in the UK in 1960. He finds that men exempt from conscription experienced an increase in earnings of between four and seven percentage points, relative to those still drafted. However, only around 1.5 percentage points can be explained by educational effects; the remainder can be attributed to the compulsory military service preventing the acquisition of work 
experience and letting human capital depreciate.

Cipollone and Rosolia (2007) estimate that an exemption from military conscription that was granted to several cohorts of males living in an South Italian area that was hit by an earthquake in 1980 raised high school graduation rates among the boys (who knew they were going to be exempted) by more than two percentage points, compared to young exempt men and older non-exempt men. Interestingly, the increase in educational attainment by boys also caused a similar increase for girls. This peer-group effect indicates that case studies on the effects of compulsory military service on the individual demand for, and performance in, education might not fully capture the human-capital effects of conscription.

Di Pietro (2009) studies the effect of the abolition of conscription in Italy (1995) on university enrollment. He finds that abolishing compulsory military service increased university participation among young males from more advantaged backgrounds, while it had a detrimental effect on the enrollment of men from less advantaged backgrounds.

In this paper, we complement this micro-econometric literature (which is theoretically based on models of individual optimization in the presence or absence of compulsory military service) by comparing the economy-wide demand for education in countries with and without conscription. Consequently, our analysis builds on a (simple) general equilibrium model that allows for different regimes of military recruitment.

\section{A Theoretical Model}

We consider an economy, populated by a large and constant number of identical individuals, where output is produced using human capital as the single factor of production. Physical capital or other inputs could be included in the model at the expense of some complexity.

\subsection{Individual decisions}

Each individual lives for one period with normalized unit length (no discounting). This time is divided into working life, education, and potentially draft. Individuals decide on how much time $s$ to invest in education. "Education" is meant to be tertiary education and is supposed to be demanded in addition to some (unmodelled) compulsory primary and secondary schooling. Becoming educated causes psychological or effort costs which can be monetarized as $C(s)$; costs and marginal costs are higher the longer study time: $C^{\prime}(s), C^{\prime \prime}(s)>0$. Higher education increases productivity $w=w(s)$ where $w^{\prime}(s)>0$.

Individual utility depends positively on the net present value of income $(=$ consumption), net of the effort cost of studying:

$$
U(s)=(1-t)(1-d-s) w(s)-C(s) .
$$


Here, $d \geq 0$ is the duration of military service and $t$ is the tax rate of a linear income tax (see below). Due to our normalization, $s$ and $d$ could alternatively be interpreted as the share of the population that is, respectively, enrolled in education or drafted into military service.

The FOC for maximizing $U(s)$

$$
(1-t)\left[-w+(1-d-s) w^{\prime}(s)\right]-C^{\prime}(s)=0
$$

implicitly defines individual investments in higher education $s=s(t, d)$ with the following properties:

$$
\begin{aligned}
& s_{t}=\frac{1}{S O C} \cdot\left[-w+(1-d-s) w^{\prime}(s)\right]<0 \\
& s_{d}=\frac{1}{S O C} \cdot w^{\prime}(s)(1-t)<0,
\end{aligned}
$$

where $S O C<0$ is the second-order condition of the optimization problem. Hence, as longer draft spells and higher taxes both reduce the marginal returns to education, individuals invest less in human capital if they are hit by either of them.

\subsection{Government and military}

The government operates a military to provide for national defense and security, the level of which will be denoted by $m$. Inputs in the production of military output are draftees, $d$, and other resources, $y$, the latter being measured in terms of income:

$$
m=M(d, y)
$$

with $M_{d}, M_{y}>0$ and the usual concavity properties of a production function. As the existence of professional armies around the world evidences, draftees are not essential in military production: $M(0, y)>0$ for all $y>0$. The case $d=0$ represent the case of an all-volunteer force. Indeed, measuring the other inputs $y$ in the same units as $(1-d-s) w(s)$ allows for interpreting these inputs as professional soldiers or, more precisely, as their labor output purchased at market conditions. In the above specification, military output only depends on the length of draft $d$, but not on the productivity of draftees. We will address this issue below. Invert $M$ to denote by

$$
y=y(d ; m)
$$

the amount of inputs other than draftees that are necessary for the production of military output $m$ if the length of draft is $d$. Obviously, the longer draft the fewer other resources are needed to produce a given output $\left(y_{d}=-M_{d} / M_{y}<0\right)$, and the higher military output, the more other resources are needed at a given 
length of draft $\left(y_{m}=1 / M_{y}>0\right)$. Conscripts are unpaid. The government, thus, only needs to finance inputs $y$ and potentially other, exogenous expenditures, with costs $\bar{g}$. Revenues are raised by an income tax. The government's budget constraint reads: $\bar{g}+y=t w(s)(1-d-s)$, or, after inserting all factors,

$$
t w(s(t, d))[1-d-s(t, d)]-y(d, m)-\bar{g}=0 .
$$

This implicitly defines the tax rate necessary to finance expenditures $\bar{g}$ and military output $m$ if the government also employs draftees with spells of $d$.

We will realistically assume that the economy operates on the increasing part of its Laffer curve. This is equivalent to assuming that financing a higher level of general government expenditures $\bar{g}$ necessitates a higher tax rate:

$$
\frac{\mathrm{d} t}{\mathrm{~d} \bar{g}}=\frac{1}{(1-d-s) w+s_{t}\left[-w+(1-d-s) w^{\prime}\right]}>0 .
$$

Under this proviso, a higher level of military output also requires an increase in the tax rate:

$$
\frac{\mathrm{d} t}{\mathrm{~d} m}=\frac{y_{m}}{(1-d-s) w+s_{t}\left[-w+(1-d-s) w^{\prime}\right]}>0 .
$$

Observe, however, that the effect of an extension of draft on tax levels is ambiguous:

$$
\frac{\mathrm{d} t}{\mathrm{~d} d}=-\frac{-y_{d}-t w+t s_{d} \cdot\left[-w+(1-d-s) w^{\prime}\right]}{(1-d-s) w+s_{t} \cdot\left[-w+(1-d-s) w^{\prime}\right]} .
$$

Here, the denominator is positive while the numerator (ignoring the minus-sign in front of the fraction) is ambiguous in sign. More unpaid draftees reduce the need to raise taxes that finance other inputs in military production $\left(-y_{d}>0\right)$ but also narrow the tax base by lowering both the size of the civilian workforce and their productivity. Hence, generally the sign of $\mathrm{d} t / \mathrm{d} d$ is unclear, although empirical studies seem to indicate that $\mathrm{d} t / \mathrm{d} d$ is indeed negative (i.e., the term $-y_{d}$ dominates).

\subsection{The total effects of draft on education}

The total (general equilibrium) effect of draft on education is now given by:

$$
\begin{aligned}
\frac{\mathrm{d} s}{\mathrm{~d} d} & =s_{d}+s_{t} \cdot \frac{\mathrm{d} t}{\mathrm{~d} d} \\
& =s_{d}-s_{t} \frac{-y_{d}-t w+t s_{d} \cdot\left[-w+(1-d-s) w^{\prime}\right]}{(1-d-s) w+t s_{t} \cdot\left[-w+(1-d-s) w^{\prime}\right]}
\end{aligned}
$$

Observation 1 Unless

$$
M_{d}>w M_{y}
$$

investment in education levels are decreasing in the duration of military draft. 
Proof: Assuming that the economy operates on the increasing part of the Laffer curve, we get:

$$
\begin{aligned}
& \frac{\mathrm{d} s}{\mathrm{~d} d} \stackrel{<}{<} 0 \\
& \Longleftrightarrow \quad s_{d}-s_{t} \frac{-y_{d}-t w+t s_{d} \cdot\left[-w+(1-d-s) w^{\prime}\right]}{(1-d-s) w+t s_{t} \cdot\left[-w+(1-d-s) w^{\prime}\right]} \underset{<}{<} 0 \\
& \Longleftrightarrow s_{d}\left[(1-d-s) w+t s_{t} \cdot\left[-w+(1-d-s) w^{\prime}\right]\right] \\
& -s_{t}\left[-y_{d}-t w+t s_{d} \cdot\left[-w+(1-d-s) w^{\prime}\right]\right] \frac{\geq}{<} 0 \\
& \Longleftrightarrow s_{d}(1-d-s) w-s_{t}\left[-y_{d}-t w\right] \stackrel{>}{<} 0 \\
& \Longleftrightarrow \quad \frac{(1-t) w^{\prime}}{S O C} \cdot(1-d-s) w-\frac{-w+(1-d-s) w^{\prime}}{S O C}\left[-y_{d}-t w\right] \frac{\geq}{<} 0 \\
& \Longleftrightarrow(1-t) w^{\prime} \cdot(1-d-s) w-\left[-w+(1-d-s) w^{\prime}\right]\left[-y_{d}-t w\right] \frac{<}{>} 0 \\
& \Longleftrightarrow(1-d-s)\left(w+y_{d}\right) w^{\prime} \frac{<}{>} w\left(y_{d}-t w\right) \text {. }
\end{aligned}
$$

In the final line, the LHS is negative from (1). Hence, a necessary condition for $\mathrm{d} s / \mathrm{d} d$ to be positive is that

$$
w<-y_{d}=\frac{M_{d}}{M_{y}}
$$

since only then the LHS can be negative.

We will now argue that condition (2) is unlikely to hold. Observe that reducing the length of the draft by one time unit means that society gains $w$ units in output (for civilian purposes). If society wishes to make up for the loss in military output from a reduction in draft time, it needs to devote additional $M_{d} / M_{y}$ units of output to military production. Condition (2) would then convey that substituting draftees by other inputs (such as to keep military output constant) reduces overall output. This contradicts all empirical studies on conscription (see, e.g., Warner and Asch, 2001, or Asch et al., 2007) which identify static efficiency losses associated with military conscription 3 Thus, unless the use of draftees in the military is considerably more productive than employing them in normal production, military conscription reduces economy-wide investment in education:

$$
\frac{\mathrm{d} s}{\mathrm{~d} d}<0 .
$$

\footnotetext{
${ }^{3}$ Consider the problem of cost-minimal production of military output: $\min \{y+w d \mid M(d, y) \geq$ $m$ \}. Optimally, we would have $M_{d}=w M_{y}$. Condition (2) then is equivalent to assuming that draftees are underutilized, relative to a cost-minimal factor allocation.
} 
As an illustration of a highly optimistic view on military conscription, assume that draftees and volunteers are perfect substitutes in military production and that draftees work in the military with their civilian productivity:

$$
M=\tilde{M}(w \cdot d+y) .
$$

Here, $M_{d}=w \tilde{M}_{y}$ such that (2) is violated. Hence, even with this pro-draft bias, conscription is unfavorable to education. If we assume that government recognizes that $s$ depends on $d$,

$$
M=\tilde{M}(w(s(d, t)) \cdot d+y)
$$

the argument would be strengthened as $M_{d}=\left(w+w^{\prime} s_{d}\right) M_{y}<w M_{y}$. Our set-up could also accommodate for the case that draftees enter the military uneducated (e.g., with productivity $w(0)$ ). Clearly, condition (2) would be violated and, thus, $\frac{\mathrm{d} s}{\mathrm{~d} d}<0$.

Observation 2 holds irrespective of whether military draft goes along with higher or lower tax rates. The (ambiguous) sign of $\frac{\mathrm{d} t}{\mathrm{~d} d}$ does not play any role; the only crucial (but realistic) condition is that the economy is on the increasing part of its Laffer curve.

The remaining comparative statics,

$$
\begin{aligned}
\frac{\mathrm{d} s}{\mathrm{~d} m} & =s_{m}+s_{t} \cdot \frac{\mathrm{d} t}{\mathrm{~d} m}<0, \\
\frac{\mathrm{d} s}{\mathrm{~d} \bar{g}} & =s_{t} \cdot \frac{\mathrm{d} t}{\mathrm{~d} g}<0
\end{aligned}
$$

give rise to the following predictions:

Observation 2 Education levels are lower the larger is military output and the larger are government expenditures and, thus, the tax rate.

As a caveat to the final statement, recall that government expenditures are assumed to be exogenous. In particular, they have to be unrelated to education. Changing this would also alter Observation 2.

Excluding the psychological time cost $C(s)$ from the model would lead to $s_{t} \equiv 0$. This trivially implies $\mathrm{d} s / \mathrm{d} d=s_{d}<0, \mathrm{~d} s / \mathrm{d} m=s_{m}<0$, and $\mathrm{d} s / \mathrm{d} g=0$.

\section{Data Description and Estimation}

Observation 1 in our model suggests that military recruitment negatively impacts human capital accumulation. In this section, we test this hypothesis empirically. Precisely, our hypothesis is that conscripted military service adversely affects the share of the working-age population participating in higher education. 
We use data for 22 OECD countries (see footnote 1) in 5-year periods. The dependent variable is the natural logarithm of the share of the working-age population participating in higher education in 1965, 1970, 1975, 1980, 1985, 1990, 1995, and 2000.4

Our econometric specification is generally in logs, except the conscription variables. It relates enrollment rates in higher education (denoted by $s_{3}$ ) to military conscription and other explanatory variables. All independent variables other than those related to conscription are averages over the five years prior to higher education.

Three alternative variables are used to measure conscription: a dummy (Conscription) for whether conscription is enforced or not, the number of conscripts as a share of the labor force (Conscripts $/ L$ ), and the duration of military draft $(D)$, each measured for the same year of the higher education variable, as that is when military draft would mainly affect higher education decisions 5

To capture the state of the economy, we include real GDP per working-age person $(y)$ as a regressor ${ }^{6}$ This variable also proxies for investment, research and development (R\&D), as well as life expectancy.

As enrollment in tertiary education typically requires completion of secondary education, we include as a regressor the share of the working-age population participating in secondary education $\left(s_{2}\right) !^{7}$

In addition to conscription, two other military variables are included to account for the size of the military and the defense situation in general: military

\footnotetext{
${ }^{4}$ The data are from World Bank (2003), unless otherwise noted. The share of the workingage population participating in higher education is calculated using the enrollment rate in tertiary education times the part of the working-age population of age 20-24. The share of the working-age population is calculated from United Nations (2003) data, while working-age population data is from World Bank (2003).

${ }^{5}$ The conscription variables are collected from IISS (various years). The labor force data is from World Bank (2004). As New Zealand's military service until at least 1980 was "voluntary, supplemented by Territorial Service of 12 weeks for the Army" (IISS, 1980: 73), which by 1985 was reduced to " 7 weeks basic [training], 20 days per year" (IISS, 1985: 130), its conscription dummy is set to 0.5 for 1965-1985. However, it is considered a country without a draft in the means calculations. When conscription duration (in years) differs between military branches, it is weighted by conscripts in each branch (or when unavailable military personnel, assuming conscripts are proportionally distributed). For Austria, we use the general conscription duration, ignoring any voluntary extension in certain military units. As IISS (1965) omits Austria and Finland, the conscription dummy and duration are extended backward from 1970 by corresponding information from Austria's Ministry of Defense (personal communication) and FINLEX (2009). The Republic of Ireland (also omitted in IISS, 1965) has never used conscription (see Irish Defence Forces, 2009). Conscripts information for Australia and the US for 1965 and 1970 is calculated from the Australian Government Department of Veterans' Affairs (2009) and the United States Selective Service System (2007), respectively.

${ }^{6}$ Data for real GDP is from Heston et al. (2000).

${ }^{7}$ The secondary education variable is calculated using the enrollment rate in secondary education times the share of the working-age population of age 15-19. The share of the workingage population of high school age (15-19) is calculated from United Nations (2003).
} 
staff as a share of the labor force $(\mathrm{Mil} / \mathrm{L})$ and military expenditures as a share of $\operatorname{GDP}(M / Y){ }^{8}$ From Observation 2 in the theoretical model, these variables should impact education negatively. To proxy the opportunity costs of education for potential students, we add the unemployment rate $(u)$ as a control variable. The general size of government is captured by government spending, exclusive of education and military expenditures, as a share of GDP. As some observations are missing, an unbalanced data set is used, consequently omitting that period's observations for the country. Our regressions exclude some outlying observations ${ }^{9}$

The pooled least square (PLS) assumption of a common constant might be too restrictive for our sample countries, and therefore the presence of fixed effects is tested to verify the appropriateness of the unrestricted fixed effects model. The relevant $F$-test rejects with wide margins for all regressions a common intercept for our sample of OECD countries. This indicates that these countries have individual country specific differences as to their shares of the working-age population participating in higher education. Thus, the unrestricted model provides unbiased, consistent and efficient estimators for our regression results.

In the unrestricted model, the regression equations for the three military conscription measures become: ${ }^{10}$

$$
\begin{aligned}
& \ln \left(s_{3}\right)_{i t}=\alpha_{i}+\beta \text { Conscription }_{i t}+X \gamma+\varepsilon_{i t} \\
& \ln \left(s_{3}\right)_{i t}=\alpha_{i}+\beta(\text { Conscripts } / L)_{i t}+X \gamma+\varepsilon_{i t} \\
& \ln \left(s_{3}\right)_{i t}=\alpha_{i}+\beta D_{i t}+X \gamma+\varepsilon_{i t} .
\end{aligned}
$$

Here,

$$
X=\left(\ln y, \ln u, \ln s_{2}, \ln (M i l / L), \ln (M / Y), \ln (G / Y)\right)_{i(t-5)}
$$

collects all regressors not related to draft (with $\gamma$ as the vector of regression coefficients).

The $\alpha_{i}$ capture country-specific fixed effects not included in the regressions (e.g., history, culture, ethnic and linguistic mixture). If country-specific constants reflect differences affected by the military structure in a country, the military variables' direct effects would be diminished.

Table 2 summarizes descriptive statistics on higher education and the use of conscription, military and other government resources.

\section{INSERT TABLE 2 HERE.}

\footnotetext{
${ }^{8}$ The data is from World Bank (2004).

${ }^{9}$ Observations with unusually high values are the conscripts share for Greece 1975-85 and for Portugal 1975 and the conscription duration measure for Portugal in 1970. Observations with unusually low values are the 1960-65 average high-school share measure for Spain, Switzerland and Turkey, and for Turkey also in 1965-70. The 1960-65 averages of the income level for Portugal and Turkey and the average unemployment rate for Switzerland 1975-85 are also unusually low. While our regressions exclude these observations, regressions including them are similar.

${ }^{10}$ Of course, coefficients may vary across models.
} 
The use of conscription has declined over time, from 17 out of the sampled 22 OECD countries enforcing conscription in 1965 to only 13 countries in the year 2000. The duration of military service has declined from an average of almost a year and a half in 1965 to less than a year in 2000 (with alternative service typically longer). The average share of the labor force drafted has also decreased over time from over 1 percent in 1965 to 0.7 percent in 2000. Countries with compulsory military service tended to have lower participation in post-secondary education (recall Table 1 as well). In 2000, the share of the working-age population enrolled in post-secondary education was on average 0.4 percentage points lower in conscription countries 11 Countries with conscription on average employed a higher share of their labor force in the military and spent relatively more on defense. They also had higher government spending, as a share of GDP, on other areas than military and education.

\section{Empirical Results}

The empirical estimates for the 5-year period panel data since the 1960s show that military conscription has a negative impact on participation in higher education (see Tables 3 to 6 ).

\section{INSERT TABLES 3 TO 6 HERE.}

The simple linear regressions in Table 3 (with fixed effects) show that enrollment in higher education is negatively correlated with each of the conscription variables (a dummy variable for its practice, duration of draft spells, and draftees' share in the labor force). However, when military draft is just represented by a dummy variable for its practice, it turns insignificant at standard levels with control variables included (see Tables 4 and 5). On the other hand, the negative impact on enrollment in higher education by the share of the labor force a nation drafts into its military remains highly statistically significant at the 1- or 5-percent level across all specifications with additional control variables. Also the duration of military service is negatively related to participation in post-secondary by the working-age population. This variable is statistically significant in all regressions, mostly at significance levels of five percent or below.

For the most conservative estimate, these results indicate that, during the sample period, a one-standard-deviation decrease of the conscript share (0.01) would be associated with an increase in the share of those enrolled in postsecondary education by at least 15 percent. Similarly, shortening the duration of military conscription by one standard deviation (by 0.66 , i.e., almost eight months) boosts enrollment in post-secondary education by at least 8 percent.

\footnotetext{
${ }^{11}$ Conscription countries also had lower participation in secondary education and lower GDP (see Keller et al., forthcoming).
} 
These are large magnitudes. The regressions are based upon the entire time period since 1965 during which the countries with a volunteer military force had generally increasingly higher rates of participation in post-secondary education compared to countries with conscription (see Tables 1 and 2).

Other variables considered also affect enrollment in higher education - without changing the statistical significance of the conscription variables (see Tables 4 to 6). The unemployment rate, secondary education enrollment in the labor force, and average income per working-age person have highly significantly positive impacts on enrollment in higher education. Higher military expenditures are associated with higher college enrollment at a significance level of one percent, while the share of military staff (professional, conscripted or a combination of both) in the labor force is rarely significant at standard levels. Government expenditures for purposes other than military or education are statistically insignificant to enrollment in post-secondary education.

To test the robustness of our results, we conducted least absolute value (LAV) (or least absolute deviation) regressions for the models in Tables 3 through $6 .{ }^{12}$ These regressions results are qualitatively similar to the ones presented in our tables and confirm that military conscription negatively impacts participation in higher education in a substantial way. Alternative regressions using instead standard tertiary (and secondary) enrollment rates yield qualitatively similar and generally highly significant results. ${ }^{13}$

\section{Conclusions}

Compared to a volunteer force, military conscription imposes a high burden on an economy, both in the form of static efficiency losses and of dynamic costs. Potential long-term costs arise from the negative impact of military draft on the demand for higher education: forced labor under conscription reduces the returns to human capital to a larger extent than a (wage-taxed financed) professional army and, thus, depresses incentives to enroll in higher education. We provide both a theoretical model and empirical evidence for this hypothesis. We show that for 22 OECD countries since the 1960s, the intensity with which military conscription is enforced has a statistically significantly negative impact on the acquiring of post-secondary education.

This result is robust in various specifications. We measure the impact of conscription by a dummy variable, by the share of conscripts in the labor force,

\footnotetext{
${ }^{12}$ As necessary to avoid singularity, we ran these regressions without a common constant and as well as with one fixed effect less than countries in the sample.

${ }^{13}$ These regressions use the natural logarithm of tertiary and secondary enrollment rates (enrolled students as a share of the usual age group for that level). Here a standard deviation decrease in the conscripts share versus the duration of conscription would increase tertiary enrollment rates by at least 10 and 6 percent, respectively. These regressions are available upon request.
} 
and by the duration of conscription service. Our regressions indicate that for a one standard deviation decrease of the duration of military conscription or of the conscript share (i.e., by almost eight months or by one percent of the population), the share of the working-age population enrolled in post-secondary education would increase by at least 8 and 15 percent, respectively. As human capital is one of the driving forces behind economic growth and prosperity, at least OECD countries appear ill-advised to rely on conscription.

\section{References}

Angrist, Josh D. (1990), 'Lifetime Earnings and the Vietnam Era Draft Lottery: Evidence from Social Security Administration Records', American Economic Review 80, 313-335.

Angrist, Josh B., and Alan B. Krueger (1994), 'Why Do World War II Veterans Earn More than Nonveterans', Journal of Labor Economics 12, 74-97.

Asch, Beth, James R. Hoseka and John T. Warner, 2007, 'New Economics of Manpower in the Post-Cold War Era'. In: Keith Hartley and Todd Sandler (eds.), Handbook of Defense Economics. Volume 2, Chapter 32. Elsevier: Amsterdam etc. Pp. 1075-1138.

Australian Government Department of Veterans' Affairs (2009), 'Conscription: The Birthday Ballot - National Service'. Online at http://vietnam-war.commemoration.gov.au/conscription/birthday-ballot. php.

Bound, John, and Sarah Turner (2002), 'Going To War And Going To College: Did World War II And The G.I. Bill Increase Education Attainment For Returning Veterans?', Journal of Labor Economics 20, 784-815.

Buonanno, Paolo (2006), 'Costs of Conscription: Lessons from the UK'. University of Bergamo, Department of Economics Working Paper No. 04/2006.

Card, David, and Thomas Lemieux (2001), 'Going to College to Avoid the Draft: The Unintended Legacy of the Vietnam War', American Economic Review 91, $97-102$.

Cipollone, Piero, and Alfonso Rosolia (2007), 'Social Interactions in High School: Lessons from an Earthquake', American Economic Review 97, 948-965. 
Di Pietro, Giorgio (2009), 'Military Conscription and University Enrolment: Evidence from Italy', IZA Discussion Paper No. 4212. IZA, Bonn.

FINLEX (2009), 'Asevelvollisuuslaki' (Finnish law on conscription), 1950 and 1998. Online at http://www.finlex.fi/fi/laki/alkup/1950/19500452 and http://www.finlex.fi/fi/laki/alkup/1998/19980019 (in Finnish).

Fisher, Anthony C. (1969), 'The Cost of the Draft and the Cost of Ending the Draft', American Economic Review 59, 239-254.

Hansen, W. Lee, and Burton A. Weisbrod (1967), 'Economics of the Military Draft', Quarterly Journal of Economics 81, 395-421.

Heston, Alan, Robert Summers, and Bettina Aten (2000), 'Penn World Table Version 6.1.' Center for International Comparisons at the University of Pennsylvania (CICUP).

IISS (various years), 'The Military Balance'. International Institute for Strategic Studies: London. Editions used: 1965, 1970, 1975, 1980, 1985, 1990, 1995, and 2000 .

Imbens, Guido, and Wilbert van der Klaauw (1995), 'Evaluating the Cost of Conscription in The Netherlands', Journal of Business and Economic Statistics $13,207-215$.

Irish Defence Forces (2009), 'History'. Online at http://www.military.ie/ dfhq/history/history.htm.

Keller, Katarina, Panu Poutvaara, and Andreas Wagener (forthcoming), 'Military Draft and Economic Growth in OECD Countries', Defence and Peace Economics.

Kerstens, Kristiaans, and Eric Meyermans (1993), 'The Draft versus an AllVolunteer Force: Issues of Efficiency and Equity in the Belgian Draft', Defence Economics 4, 271 - 284.

Kunze, Astrid (2002), 'The Timing of Careers and Human Capital Depreciation', IZA Discussion Paper No. 509. IZA, Bonn.

Lau, Morten I., Panu Poutvaara, and Andreas Wagener (2004), 'Dynamic Costs of the Draft', German Economic Review 5, 381-406.

Lee, Dwight R., and Richard B. McKenzie (1992), 'Reexamination of the Relative Efficiency of the Draft and the All-Volunteer Army', Southern Economic Journal 
$59,646-654$.

Maurin, Eric, and Theodora Xenogiani (2007), 'Demand for Education and Labor Market Outcomes: Lessons from the Abolition of Compulsory Conscription in France,' Journal of Human Resources 42, 795-819.

Sandler, Todd, and Keith Hartley (1995), The Economics of Defense, Cambridge University Press: Cambridge.

Spencer, Daniel L., and Alexander Woroniak (1969), 'Valuing Transfer of MilitaryAcquired Skills to Civilian Employment', Kyklos 22, 467-492.

United Nations (2003), 'World Population Prospects: The 2002 Revision', Population Division, Department of Economic and Social Affairs.

United States Selective Service System (2007), 'History and Records: Induction Statistics'. Online at http://www.sss.gov/induct.htm.

War Resisters' International (1998), 'Refusing to Bear Arms: A World Survey of Conscription and Conscientious Objection to Military Service', War Resisters' International: London. Online at http://www.wri-irg.org/co/rtba/index. html.

Warner, John T., and Beth J. Asch (1995), 'The Economics of Military Manpower', in: Keith Hartley and Todd Sandler (eds.), Handbook of Defense Economics, Vol. 1. Elsevier: Amsterdam. 348-398.

Warner, John T., and Beth J. Asch (2001), 'The Record and Prospects of the All-Volunteer Military in the United States', Journal of Economic Perspectives 15, 169-192.

World Bank (2003), 'WDI Online', World Development Indicators, World Bank: Washington D.C.

World Bank (2004), 'World Development Indicators 2004 CD-ROM', World Bank: Washington D.C. 
Table 1: Post-Secondary Education/College Age (Means) ${ }^{a}$

\begin{tabular}{c|ccc} 
& All countries & No conscription & \\
& & Conscription $^{b}$ \\
\hline \hline 1965 & 0.136 & 0.156 & 0.130 \\
1970 & 0.178 & 0.227 & 0.163 \\
1975 & 0.241 & 0.302 & 0.211 \\
1980 & 0.264 & 0.332 & 0.229 \\
1985 & 0.298 & 0.375 & 0.260 \\
1990 & 0.388 & 0.477 & 0.344 \\
1995 & 0.513 & 0.611 & 0.457 \\
2000 & 0.570 & 0.588 & 0.558 \\
\hline
\end{tabular}

Notes:

a: Calculations based on WDI data are published with permission from the World Bank.

b: $\quad$ Out of 22 countries, 17 enforced conscription between 1965 and 1970, 15 between 1975 and 1990, 14 in 1995, and 13 in 2000.

Data for Germany is included since 1995. 
Table 2: Descriptive Statistics (Means) ${ }^{a}$

\begin{tabular}{|c|c|c|c|}
\hline & All countries & No conscription ${ }^{b}$ & Conscription $^{b}$ \\
\hline \multicolumn{4}{|c|}{ Conscripts/Labor Force: } \\
\hline 1965 & & & 0.011 \\
\hline 1970 & & & 0.009 \\
\hline 1975 & & & 0.015 \\
\hline 1980 & & & 0.013 \\
\hline 1985 & & & 0.012 \\
\hline 1990 & & & 0.012 \\
\hline 1995 & & & 0.008 \\
\hline 2000 & & & 0.007 \\
\hline \multicolumn{4}{|c|}{ Length of Military Service: } \\
\hline 1965 & & & 1.426 \\
\hline 1970 & & & 1.478 \\
\hline 1975 & & & 1.208 \\
\hline 1980 & & & 1.123 \\
\hline 1985 & & & 1.083 \\
\hline 1990 & & & 1.052 \\
\hline 1995 & & & 0.921 \\
\hline 2000 & & & 0.893 \\
\hline \multicolumn{4}{|c|}{ Post-Secondary Education/Labor Force: } \\
\hline 1965 & 0.016 & 0.019 & 0.015 \\
\hline 1970 & 0.023 & 0.031 & 0.021 \\
\hline 1975 & 0.030 & 0.040 & 0.025 \\
\hline 1980 & 0.033 & 0.044 & 0.027 \\
\hline 1985 & 0.037 & 0.049 & 0.031 \\
\hline 1990 & 0.045 & 0.055 & 0.040 \\
\hline 1995 & 0.056 & 0.067 & 0.049 \\
\hline 2000 & 0.056 & 0.059 & 0.055 \\
\hline \multicolumn{4}{|c|}{ Military Staff/LaborForce: } \\
\hline 1985-1990 & 0.016 & 0.009 & 0.020 \\
\hline 1990-1995 & 0.015 & 0.009 & 0.018 \\
\hline $1995-2000$ & 0.013 & 0.008 & 0.017 \\
\hline \multicolumn{4}{|c|}{ Military Expenditures/GDP: } \\
\hline $1985-1990$ & 0.025 & 0.025 & 0.026 \\
\hline 1990-1995 & 0.023 & 0.022 & 0.024 \\
\hline 1995-2000 & 0.020 & 0.018 & 0.022 \\
\hline \multicolumn{4}{|c|}{ Government Expenditures (excl. Education and Military Spending)/GDP } \\
\hline $1985-1990$ & 0.115 & 0.105 & 0.119 \\
\hline 1990-1995 & 0.120 & 0.112 & 0.125 \\
\hline $1995-2000$ & 0.118 & 0.117 & 0.119 \\
\hline
\end{tabular}

Notes as in Table 1. 
Table 3

Dependent Variable: Ln Tertiary Enrollment / Labor Force (1965-2000)

$\begin{array}{lccc}\text { Constant } & -3.005 & -2.819 & -2.904 \\ & (0.083)^{* * *} & (0.058)^{* * *} & (0.095)^{* * *} \\ \text { Conscription Dummy } & -0.653 & & \\ & (0.108)^{* * *} & & \\ \text { Conscripts/Labor Force } & & -80.986 \\ & (8.023)^{* * *} \\ \text { Length of Military Service } & & -0.698 \\ & & (0.121)^{* * *} \\ & & \\ \bar{R}^{2} & & 0.442 \\ \text { Observations } & 170 & 169 \\ \text { Countries } & 22 & 22 & 22 \\ \text { Note: } *(* *)[* *] \text { denotes significance at the } 10 \%(5 \%)[1 \%] \text { level. } \\ \text { Standard errors in parentheses. Fixed effects are not reported. }\end{array}$


Table 4

Dependent Variable: Ln Tertiary Enrollment / Labor Force (1965-2000)

Constant

$-18.902$

$-15.621$

$-17.968$

$(1.055)^{* * *}$

$(1.556)^{* * *}$

$(1.139)^{* * *}$

Conscription Dummy

$-0.072$

$(0.107)$

Conscripts/Labor Force

$-28.417$

$(8.167)^{* * *}$

Length of Military Service

0.159

$(0.076)^{* *}$

GDP/Working-Age Person

1.553

1.239

1.467

$(0.103)^{* * *}$

$(0.151)^{* * *}$

$(0.111)^{* * *}$

$\bar{R}^{2}$

0.814

0.794

0.816

Observations

168

146

167

Countries

22

22

22

Note: $\quad *(* *)[* * *]$ denotes significance at the $10 \%(5 \%)[1 \%]$ level.

Standard errors in parentheses. Fixed effects are not reported. 
Table 5

Dependent Variable: Ln Tertiary Enrollment / Labor Force (1965-2000)

$\begin{array}{lccc}\text { Constant } & -13.116 & -11.167 & -12.720 \\ & (1.259)^{* * *} & (1.095)^{* * *} & (1.250)^{* * *} \\ \text { Conscription Dummy } & -0.124 & & \\ & (0.086) & & \\ \text { Conscripts/Labor Force } & & -23.941 & \\ & & (5.422)^{* * *} & \\ \text { Length of Military Service } & & & -0.126 \\ & & & (0.052)^{* *} \\ \text { GDP/Working-Age Person } & 1.159 & 0.984 & 1.113 \\ & (0.102)^{* * *} & (0.097)^{* * *} & (0.104)^{* * *} \\ \text { Secondary Enrollment } & 0.784 & 0.842 & 0.749 \\ & (0.126)^{* * *} & (0.119)^{* * *} & (0.121)^{* * *}\end{array}$

$\bar{R}^{2}$

0.857

0.849

0.856

Observations

166

145

165

Countries

22

22

22

Note: $\quad *(* *)\left[{ }^{* *}\right]$ denotes significance at the $10 \%(5 \%)[1 \%]$ level.

Standard errors in parentheses. Fixed effects are not reported. 


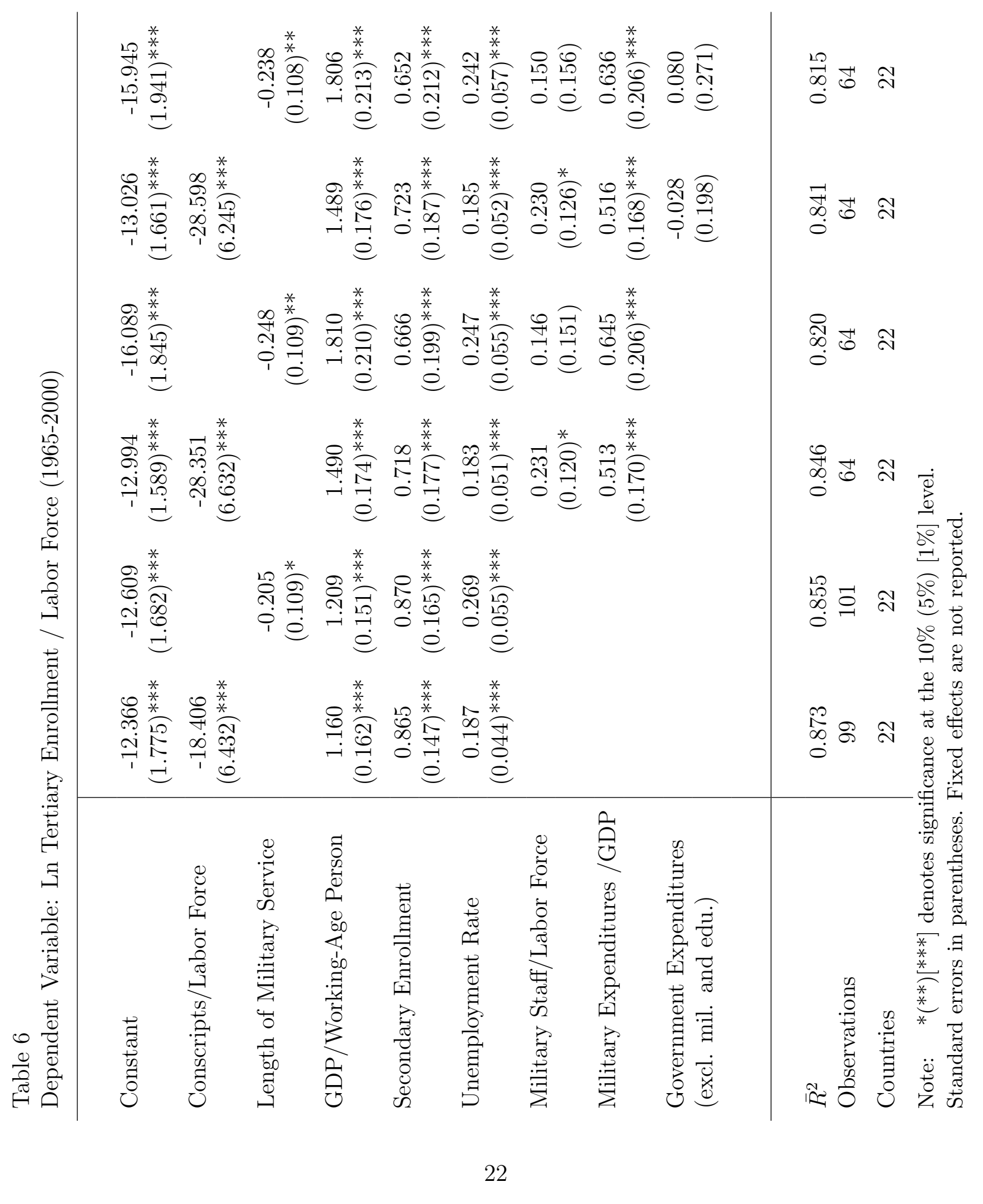

